\title{
ASPECTOS RETÓRICOS NO GÊNERO TEXTUAL MEME NA INTERNET
}

\author{
José Nildo Barbosa de Melo Junior* \\ Eduardo Pantaleão de Morais** \\ Maria Francisca Oliveira Santos ${ }^{* * *}$
}

RESUMO: Este artigo tem por finalidade analisar especificidades retóricas no gênero textual meme, notadamente as funções retóricas e a ironia como uma figura retórica, em memes da internet. A metodologia adotada para o estudo dos memes é de cunho qualitativo, descrevendo e interpretando as idiossincrasias linguísticas que fazem o referido gênero acontecer, no que diz respeito às funções retóricas e à figura retórica ironia, bem como tornando a análise qualitativa um processo contínuo de construção de versões da realidade (FLICK, 2009). A amostragem para as análises é composta por memes disponíveis na web. Os pressupostos teóricos baseiam-se na Retórica Moderna, a partir de Meyer (2007), Perelman, Olbrechts-Tyteca (1996), Reboul (1998), Sousa (2001), entre outros, bem como se alicerçam nos estudos de Barreto (2015), Horta (2015) e Calixto (2017), os quais trazem discussões acerca do gênero textual meme. Os resultados apontam que os memes apresentam mecanismos retóricos, com vistas a discutir problemas sociais controversos, por meio da sustentação de opiniões ou refutação de tomadas de posição pelos retores enquanto sujeitos das práticas sociais de linguagem. A relevância da temática dá-se por trazer uma abordagem argumentativa do gênero meme na internet, com fundamento na perspectiva da Retórica Moderna.

PALAVRAS-CHAVE: Funções retóricas; Internet; Ironia; Meme; Retórica Moderna.

\section{Considerações preliminares}

Este artigo visa analisar aspectos argumentativos, numa abordagem retórica, mostrando como os retores podem construir e recuperar sentidos no gênero textual meme, em circulação na internet, tornando possíveis a identificação e a interpretação de elementos retóricos, utilizados pelos produtores dos memes (retor ${ }^{1}$ ), com a finalidade de estabelecer um diálogo persuasivo com os seus leitores.

\footnotetext{
* Mestre e doutorando em Linguística pela Universidade Federal de Alagoas (Ufal).

** Doutor em Letras Universidade Estadual de Maringá (Uem). Professor da Universidade Estadual de Alagoas (Uneal).

*** Doutora em Letras pela Universidade Federal de Pernambuco (UFPE). Professora da Uneal e do Programa de Pós-Graduação em Linguística e Literatura da Universidade Federal de Alagoas (Ufal).

1 O termo retor será utilizado para referenciar o produtor de memes, e o termo auditório, para indicar os internautas que acessam os memes veiculados na web e nas redes sociais.
} 
A discussão se justifica por investigar como se deram as estratégias argumentativas à luz das funções retóricas e da figura retórica ironia, com vistas a requerer uma maior adesão do auditório. Assim, tais categorias persuasivas forjam um caráter de maior poder argumentativo nos textos produzidos em diversos ambientes, caracterizados como textos de natureza midiática, humorística, jornalística, sendo os memes analisados ambientados digitalmente (web).

Do ponto de vista teórico-metodológico, conforme já sinalizado, o gênero textual que serve de amostragem para a realização da análise argumentativa é o meme, gênero midiático que circula entre, pelo menos, três esferas da comunicação, a humorística, a cotidiana e a jornalística, e, por sua vez, comporta um olhar particular daquele que produz esse gênero, trazendo como marca central assuntos de interesse da sociedade. Para isso, realiza-se uma caracterização do meme, das categorias textuais e argumentativas a serem observadas nesse gênero, compondo, por assim dizer, a forma como se apresenta diante da sociedade leitora na web, em nível nacional.

Por ser o meme um gênero de grande circulação, no ambiente midiático, o qual apresenta um significativo movimento de sentidos, a análise descritivo-interpretativa mostrou como a tríade argumentativa se institui, como as funções retóricas e a figura retórica ironia se constituem nos memes, na internet; e de que forma a argumentação produziu e recuperou sentidos, revelando o posicionamento crítico daquele que se pronuncia ou escreve o texto.

\section{O gênero textual meme}

$\mathrm{Na}$ atual conjuntura de um mundo cada vez mais globalizado e disposto de ferramentas multimidiáticas, com o intuito de obter novas possibilidades de interação, aprendizagem, consolidação desta ou mesmo como dispositivo metodológico de ensino, e com o objetivo de atender a necessidades, muitas vezes, triviais na sociedade, o homem tem se adaptado aos usos sociais das mídias e das redes sociais, desenvolvendo habilidades que os tornam capazes de estabelecer relações sociointeracionais num nível mais amplo e a reagir às diversas questões políticas, ambientais, educacionais, além de outras, que emanam da 
sociedade, defendendo pontos de vista, satirizando ou criticando fatos, acontecimentos ou personalidades, a partir de opiniões expressas em textos.

A inserção das tecnologias na vida cotidiana tem ressignificando ou ressemiotizado as formas de interação ou comunicação entre pessoas, exigindo competências que favoreçam novas práticas de leitura, configurando e reconfigurando a web, por intermédio das ferramentas da chamada Web 2.0 (Blog, Facebook, Twitter, Whatsapp, Youtube, Instagram, entre outros), permitindo aos usuários não somente consumirem a informação, como também produzi-la (GOMES, 2016). Nesse sentido, as transformações apresentadas pelas novas tecnologias da informação e comunicação e os meios de acesso à informação e produção de conteúdos já são uma realidade vivida pela sociedade nos dias atuais, e isso tem acarretado inúmeras mudanças nas práticas interacionais e sociodiscursivas.

Inserem-se, nesse contexto, os memes na internet que trazem recursos multimodais e argumentativos, a fim de manifestar opiniões, refletir acerca de situações cotidianas e ironizar algo ou alguém. Os memes contribuem para a compreensão do discurso e dos pontos de vista, (logos), ao revelarem estados afetivos, emocionais, sentimentos, relações interpessoais (pathos), a partir de modos e habilidades comunicativas que incluem não apenas estratégias verbais do orador (ethos), mas ainda estratégias multimodais, incluindo os não verbais.

O conceito do termo meme foi forjado por Richard Dawkins, em 1976, em seu livro O Gene Egoísta. Em seu estudo acerca da evolução, o autor estabelece uma comparação entre gene e meme - transmissão genética e transmissão cultural, respectivamente -, ao salientar que as ideias, os conceitos, valores e comportamentos produzidos socialmente se propagam como os genes humanos. O termo provém do grego mímesis, que significa imitação, sua aférese do inglês mimeme consolidou-se em meme, no português. A etimologia da palavra meme justifica o fato de os memes serem caracterizados como replicadores socioculturais que reproduzem cópias, imitações e manifestações de percepções que as pessoas têm sobre uma dada realidade e que se configuram em imagens, montagens com fotos, vídeos e GIFs, com o intuito de parodiar, satirizar, criticar ou refletir a respeito de situações do cotidiano (CALIXTO, 2017). 
Se o gene é uma unidade de reprodução biológica, o meme é uma unidade de reprodução cultural. Enquanto unidade que se replica e se transmite culturamente, o processo evolutivo dos memes, comparado ao dos genes, baseia-se em três processos: o de mutação ou variação, por o meme sofrer variações mais ou menos significativas, ao circularem nas mídias; seleção natural, por haver memes que recebem mais ênfase e atenção que outros, permanecendo ativos e sendo replicados por mais tempo, enquanto outros caem no esquecimento rapidamente; hereditariedade ou retenção, por uma ideia original permanecer ao longo das mutações cada vez que um novo meme é criado, recombinado e sofre variações (BARRETO, 2015; HORTA, 2015; CALIXTO, 2017).

Assim, para sobreviverem no meio sociocultural, os memes devem ter longevidade (habilidade de permanecer no tempo), fecundidade (habilidade de gerar cópias), fidelidade das cópias (habilidade de gerar cópias muito semelhantes ao meme original) e expansividade (habilidade de se expandir pelas redes sociais), o que tem uma influência profunda do fator espaciotemporal e dos recursos audiovisuais, multimodais, verbo-visuais disponíveis e utilizados, além da capacidade cognitiva, textual e comunicacional, já que os memes também são replicadores de efeitos de sentido e de vias de acesso ao sentido do texto, a exemplo do hibridismo textual, da intertextualidade e seus desdobramentos (BARRETO, 2015; HORTA, 2015; CALIXTO, 2017).

Nesse tocante, convém pensar sobre o fato de os gêneros acompanharem a dinâmica das interações sociais, visto que emergem dessas relações e das inúmeras práticas comunicativas que circundam o mundo. O gênero textual meme na internet participa, evidentemente, desse circuito, não somente por emanar do espaço midiático, mas também pelas várias finalidades sociocomunicativas e das dimensões e sequências textuais, com base nas quais, além de outras, é criado. Calixto (2017) concebe os memes como composições híbridas, micronarrativas originadas de narrativas - que circulam no ciberespaço - e construídas por meio de montagens, recortes e remodelagens, compartilhados on-line e difundidos nas redes sociais, rapidamente, com o objetivo de elaborar e narrar relações e peri- 
pécias do cotidiano; essas micronarrativas operam a partir das representações e das produções de sentido que emanam das atividades cotidianas, sintetizando e referenciando conteúdos e discursos propagados socialmente nas relações dinâmicas do ciberespaço.

Fundamentando-se em tais apontamentos teóricos, seria equivocado e reducionista enquadrar o gênero textual meme num domínio social de comunicação específico, com natureza tipológica e capacidade de linguagem única, diante das significativas transformações por que esse gênero passa, ao circular na internet, sobretudo ao refletir sobre os vários objetivos de produção ou replicação de memes, seu caráter altamente maleável, as diversas necessidades comunicacionais de se operar com a linguagem e os contextos histórico-sociais a que pertencem. Isso é, realmente, possível, quando se pensa na coexistência entre o real e o virtual no meme, pois, segundo Calixto (2017), há uma relação híbrida entre ambos, de modo que as significações e os sentidos condicionados pela linguagem nos memes estão intrinsicamente ligados às interações cotidianas e sociais.

Como uma composição textual moldável às práticas sociocomunicativas, a imagem 1 possibilita analisar a complexidade de se estabelecer os limites de um aspecto tipológico e de uma capacidade de linguagem específica, em função do que traz o meme que representa a imagem 1. Se, por um lado, o retor relata uma experiência que gerava insatisfação, vivida por uma professora, ao ser chamada de tia, o propósito comunicativo da imagem apontada é ratificado pelas duas falas seguintes "Pior é ser chamada de Vó, ou pior, BISA" e "Nós éramos felizes e não sabíamos!!!!", que, mesmo produzidas de forma bem humorada, censuram a reforma previdenciária, sustentando uma tomada de posição, a de que é contra o projeto e não defende tal proposta. 
Imagem 1 - Reforma da previdência para professores

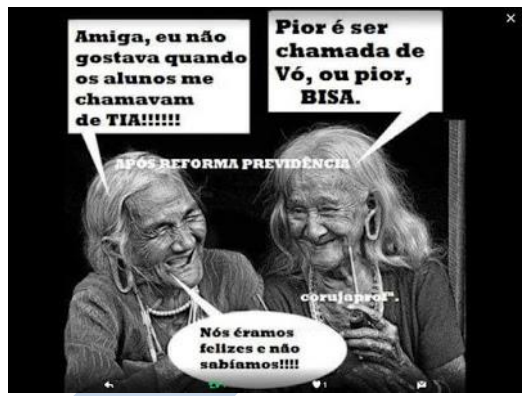

Fonte: Disponível em: http://www.jornalis.com.br/2017/01/mem es-sobre-reforma-da-previdencia-em.html. Acesso em 27 fev. 2020.

Na imagem 1, o tópico abordado é o projeto de reforma da previdência, proposta que vem gerando críticas nas redes sociais e na web. A crítica levantada pelo retor (éthos), que toma por auditório social os professores (pathos), suscita a questão da idade mínima, não apenas pelas implicações e problemas sociais enfrentados pela maior parte dos professores ao longo da carreira, mas ainda por conceder a aposentadoria, obrigatoriamente, num estágio avançado da vida. Como a proposta eleva essa idade, se for aprovada, a categoria não terá mais o direito à idade diferenciada e será equiparada às regras impostas a outros trabalhadores, daí a crítica feita pelo retor, quando mostra, na interação entre as duas senhoras, que, com a concretização da proposta, os alunos deixarão de chamá-la de tia, o que já não era agradável a ambas, e passarão a chamá-las de avó ou bisavó.

Nesse sentido, a análise qualitativa, neste artigo, permite identificar e interpretar como os sentidos são produzidos nos memes, a partir de categorias argumentativas, considerando ser um gênero de uma estrutura retórica dinâmica, o que prova sua flexibilidade quanto à forma, incluindo os aspectos tipológicos, já que o meme é um texto midiático breve, de alta capacidade sintética, que, além de abranger a tipologia do narrar, ao representar uma recriação da realidade, do domínio verossímil, pode se inserir na tipologia do argumentar, na qual se discutem problemas sociais controversos, por meio da sustentação, refutação e negociação de tomadas de posição (DOLZ, SCHNEUWLY, 2004), mas também é um texto que pode aparecer com o fito de relatar, documentar e memorizar ações 
humanas, a partir da representação pelo discurso de experiências vividas e situadas no tempo.

\section{A Retórica}

A Retórica, ao longo dos séculos, passou por um processo de ressignificação, em virtude das várias faces construídas por teóricos, sobretudo pelas necessidades de uso do discurso $^{2}$ persuasivo pelos falantes de uma língua, com o intuito de defender pontos de vista, por meio de argumentos e de um fazer retórico. Os construtos teóricos que revitalizaram cientificamente os estudos retóricos partem da Antiga à Nova Retórica, que aponta as estratégias argumentativas de que se serve o retor para conquistar a adesão de um auditório acerca de um determinado assunto, tais como: a escolha de um determinado argumento (técnicas argumentativas), a utilização de figuras de retórica, de premissas argumentativas e outras.

Não há como proceder a uma análise retórica sem definir a Retórica, da mesma forma que não há como escapar do propósito da argumentação na linguagem, considerando que esta permeia o cotidiano das pessoas. Meyer (2007, p. 21) aponta três concepções possíveis de retórica: a) manipulação do auditório (Platão); b) exposição de argumentos ou de discursos que devem ou visam a persuadir (Aristóteles) e c) arte de bem falar (Quintiliano).

Da primeira definição, depreende-se que a retórica focaliza a manipulação de um auditório por meio da oratória, que tem como objetivo emocionar o auditório em todas as suas motivações (pathos), o que convergia para a persuasão. $\mathrm{Na}$ segunda, constata-se que a retórica é, na verdade, o envolvimento do auditório por meio das paixões decorrentes da imagem passada pelo orador, do objetivo da mensagem, visando às melhores estratégias linguísticas para tornar o discurso (logos) atrativo e infalível na persuasão dos auditórios.

${ }^{2}$ A Retórica apropria-se do discurso persuasivo ou do que o discurso tem de persuasivo. Neste artigo, discurso consiste em toda produção verbal, escrita ou oral, que se constitui por frases, períodos, parágrafos ou textos e apresenta sentido (REBOUL, 1998). 
$\mathrm{Na}$ terceira definição, identifica-se a retórica como sendo a arte do bem falar e que possui as melhores qualidades do discurso e da moralidade do orador (ethos). Ainda que esse momento da retórica estivesse voltado para uma arte do bem dizer, manifestaria uma preocupação para com o auditório.

Defender aquilo que se pensa ou refutar aquilo que se ouve exige do retor e do auditório social a capacidade linguística de argumentar ou de negociar os argumentos. Essa capacidade é uma arte, porque manipular a linguagem para atender a objetivos é uma manifestação de arte, por meio da palavra, que se reveste de sentido e de poder. Infere-se, desse modo, para a possibilidade de a Retórica ser a arte de persuadir pelo discurso, por meio de argumentos negociáveis em contexto interativo, e está presente em qualquer texto, oral ou escrito, que tem por finalidade persuadir.

No âmbito da argumentação, as três definições mencionadas anteriormente estão intrinsecamente ligadas à tríade aristotélica: ethos/pathos/logos. No estabelecimento das relações retóricas, o retor (ethos), as paixões do auditório (pathos) e a linguagem (logos) são igualmente fundamentais ${ }^{3}$. Nas dimensões constitutivas da relação retórica e com vistas à argumentação, o retor e o auditório social negociam sua distância, suas concepções distintas, seus questionamentos, por meio de uma linguagem persuasiva ou discurso persuasivo na prática comunicativa. Nesse sentido, de acordo com Meyer (2007, p. 26): “[...] A retórica é a análise dos questionamentos que são feitos na comunicação interpessoal e que a suscitam ou nela se encontram".

Em uma sociedade, regida pelas relações de interesses, diferentes grupos sociais agem retoricamente, a fim de alcançar seus objetivos, por meio de um conjunto de práticas e técnicas argumentativas. Desse modo, várias definições explicitam bem o propósito de

${ }^{3}$ Para Meyer (2007, p. 25), “[...] o ethos, o pathos e o logos devem ser postos em pé de igualdade, se não quisermos cair em uma concepção que exclua as dimensões constitutivas da relação retórica. O orador, o auditório e a linguagem são igualmente essenciais". Notadamente, nesse jogo argumentativo, o ethos, o pathos e o logos exercem o mesmo grau de importância, destacando-se, de forma diferenciada, em cada momento discursivo. O ethos referese ao caráter assumido pelo orador, para inspirar confiança no auditório, é a imagem forjada pelo retor, associada aos seus argumentos. O pathos vincula-se aos sentimentos, às emoções, às paixões do auditório, suscitadas pelo orador. A paixão em Retórica refere-se ao temor, esperança, ódio, desespero, desejo, isto é, a todos os sentimentos presentes no auditório. O logos refere-se à argumentação propriamente dita. 
agir de maneira retórica nas mais diversas instâncias discursivas, a fim de conjugar as diferenças existentes entre os interlocutores.

Nos estudos da comunicação humana, segundo Halliday (1999, p. 9), a Retórica "ocupa-se de examinar, descrever, prescrever e avaliar atos e eventos que visem influenciar percepções, sentimentos, atitudes e ações, com palavras e outros símbolos”. Essa retórica torna-se multiforme, pois as pessoas descrevem, explicam e justificam fatos, interesses, buscando o entendimento de um auditório e negociando entre si as diferenças.

Segundo Perelman, Olbrechts-Tyteca (1996), qualquer argumentação tem como objetivo levar os espíritos à adesão das teses defendidas. Por isso, na opinião dos autores, os efeitos práticos da argumentação voltam-se ao futuro, uma vez que provocam uma ação ou preparam para ela, por meio de mecanismos discursivos que induzem ou aumentam a adesão dos espíritos dos ouvintes às teses (PERELMAN, OLBRECHTS-TYTECA, 1996). Nesse sentido, de alguma forma, o argumento incita escolhas, desencadeia reações ou suscita ações, conforme se verifica nas imagens 2 e 3 .



Fonte: Disponível em: <http://deboradebonis.blogspot.com/2014/06/filosofia-meme-dia-mundial-do-meio.html>. Acesso em 27 fev. 2020 


\section{Imagem 3 - Dia mundial do meio ambiente}



Fonte: Disponível em: <http://deboradebonis.blogspot.com/2014/06/filosofia-meme-dia-mundial-do-meio.html>. Acesso em 27 fev. 2020

As imagens 2 e 3 circularam na rede, em homenagem ao dia mundial do meio ambiente, cujo tópico a ele se refere, constituem uma reação a ações humanas sustentavelmente depreciadas, quando os retores fazem apologia ao desmatamento, em ambas as imagens, como falta de conscientização e de responsabilidade social, e criticam a partir do jogo de palavras "As sementes fazem as árvores. Os sem-mentes desfazem as florestas", reforçado pelo não verbal. Além disso, o retor ironiza tal prática, na imagem 3, ao plurissignificar o termo "meio", em "meio ambiente", atribuindo ao elemento "meio" o sentido de metade, por as pessoas terem destruído metade da natureza, e não observando a etimologia da palavra "meio ambiente", cuja origem se funda no latim medius, que significa "meio, intermediário, o que está entre duas partes" e ambiente, do Latim ambiens, que significa "volta ao redor", conceituando-a como aquilo que está entre coisas vivas e não vivas na Terra, numa relação. O humor se constrói por intermédio do conteúdo, com o propósito consistente de corrigir a ação humana de desmatar, destruir a natureza, e de, ao mesmo tempo, criticar essa realidade, ironizando com base nas referidas palavras-chave das imagens.

Tomando esse propósito, apoia-se em Perelman, Olbrechts-Tyteca (2005), ao afirmarem que argumentar é uma ação que tende sempre a modificar um estado preexistente de coisas, quando o seu uso implica a renúncia a uma força e o apreço dado à adesão do interlocutor, por meio da persuasão fundada num raciocínio. A argumentação está presente 
em discursos em que o retor procura interferir nos julgamentos, nas opiniões e preferências do outro, elucidando seu ponto de vista, o que permite dizer, nesse sentido, que a linguagem é, por essência, argumentativa, por se negociarem ideias, conceitos, opiniões em diferentes situações comunicativas.

A argumentação é definida também como a "arte de, gerenciando informação, convencer o outro de alguma coisa no plano das ideias e de, gerenciando relação, persuadi-lo, no plano das emoções, a fazer alguma coisa que nós desejamos que ele faça” (ABREU, 2004, p. 26). Persuadir é levar o auditório a crer em alguma coisa, e convencer consiste em fazê-lo compreender algo ou algum acontecimento, isso porque a persuasão dá-se no plano das emoções (pathos), e o convencimento concretiza-se no plano das ideias, da razão (logos), por isso não atinge o auditório em sua totalidade. Por vezes, é possível convencer as pessoas; não sendo fácil persuadi-las. Assim, argumentar é um modo específico de produzir sentidos que permitam a mudança de um comportamento, de uma ideia ou mesmo de uma posição política de um auditório.

Os discursos persuasivos podem formar, reformar ou conformar pontos de vista e perspectivas colocadas em movimento por retor e auditório social. Formar é construir novas ideias, opiniões, novos pontos de vista, a partir das relações homem-mundo-sociedade; reformar consiste em redirecionar comportamentos, ideias, conceitos já existentes; conformar significa reiterar, retomar algo já mencionado no texto, posições já existentes, forjar sentidos ou, ainda, relembrar, ratificar uma afirmação (CITELLI, 2005), o que ocorre na imagem 4, quando o retor constrói um ponto de vista diante do seu auditório social, os professores, acerca da inserção destes no projeto de reforma da previdência, e revela um comportamento que vai de encontro aos ideias da referida Proposta de Emenda Constitucional. 
Imagem 4 - Reforma da previdência para professores

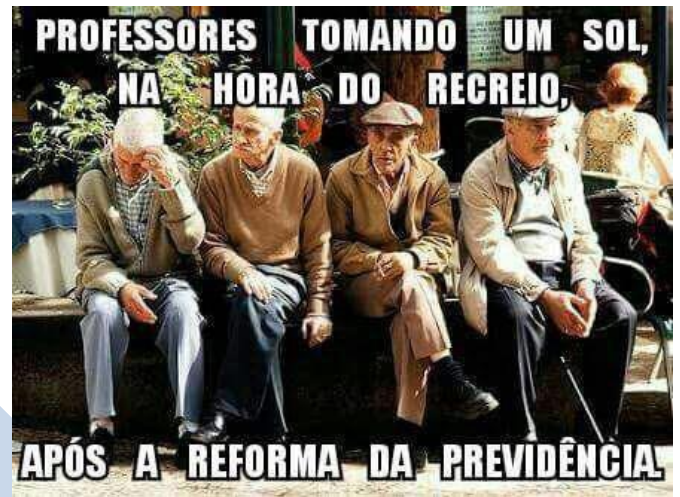

Fonte: https://www.revistaforum.com.br/dez-memes-sobre-a-reforma-da-previdencia/. Acesso em: 20 fev. 2020.

$\mathrm{Na}$ imagem 4, retoma-se a crítica ao projeto de reforma da previdência, o qual abrange os professores. A sátira feita pelo retor (ethos) não reside no fato de os senhores, assim como a maioria dos seres vivos, precisarem tomar sol, já que constitui uma questão de saúde, mas está no fato (logos) de que a escola, instituição de trabalho, não seria o local mais apropriado para tomar sol nessa idade, o que, possivelmente, não torna isso um ato de vontade dos professores (pathos), o que caracteriza a ironia e mostra que o aumento da idade mínima e a inclusão dessa classe no projeto não são tão positivos quanto parecem.

\subsection{Os gêneros do discurso retórico}

Conforme Aristóteles (2005), o discurso é composto por três elementos: aquele que fala, aquele ou aquilo sobre o que se fala e aquele a quem se fala, e nele atuam três tipos de ouvinte - o espectador que observa o presente; a assembleia que se volta para o futuro; e o juiz que tem o poder de julgar coisas passadas. Nesse contexto, estão inseridos os três gêneros do discurso definidos pelo referido teórico, tomando por base o auditório, a finalidade e o contexto.

O gênero epidíctico (demonstrativo) tem por objetivo elogiar/louvar ou censurar fatos, demarcar a importância e a nobreza do próprio homem, de seus valores, ou ainda, 
criticar o homem, depreciar suas atitudes, ideias e seus valores. O discurso epidíctico centra-se nos espectadores como auditório e refere-se ao tempo presente, pois o elogio e a censura baseiam-se no estado presente das coisas, embora o retor, possivelmente, recorra a argumentos do passado e do futuro, o que se ilustra na imagem 5 .

Imagem 5 - Saída dos médicos cubanos do programa Mais Médicos

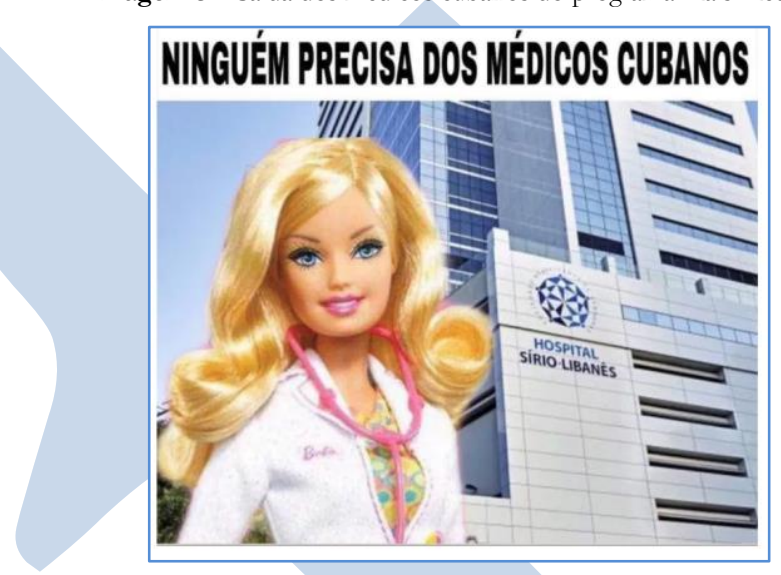

Fonte: https://www.humorpolitico.com.br/category/memes/page/5/. Acesso em: 20 fev. 2020.

A imagem 5 explora como tópico a retirada dos médicos cubanos do programa Mais Médicos. A decisão do governo de Cuba de retirar 8.332 médicos que prestavam serviço no Brasil foi executada, quando o atual governo brasileiro criticou o sistema cubano de governo e a forma como vigorava o acordo entre os médicos cubanos e seu país. Se, por um lado, Cuba sofreu um prejuízo econômico significativo com o rompimento, por outro lado, a saída repentina desses médicos dos postos e unidades de saúde de todo país, potencializando os problemas de saúde pública no Brasil, sobretudo em áreas mais remotas e vulneráveis, por inúmeras vagas para as quais os médicos se inscreveram não terem sido preenchidas efetivamente.

Isso explica o ato de ironia e censura da imagem 5, significando o contrário de "Ninguém precisa dos médicos cubanos", ao pensar no público que carece desse serviço, pois, em meio a falta de médicos e de suprimentos no país, um grupo que pertence a uma 
seleta classe, incluindo as próprias autoridades, não precisam do serviço de saúde que era oferecido pelo programa, visto que dispõem de serviço de saúde com qualidade, em hospitais com médicos renomados e tecnologia de ponta. Além disso, a boneca representada na imagem traduz que formar médicos de raça negra e classe pobre no Brasil é algo distante, porque o percentual de negros e pobres que acessam cursos tidos como os mais elitizados é ínfimo, na área da Medicina, do Direito e das Engenharias.

Quanto aos demais gêneros do discurso retórico, o demonstrativo prima por discursos mais bem elaborados, agradáveis e atraentes, possibilitando que estes sejam aceitos e mais bem acolhidos pelo auditório. Assim, o epidíctico ocupa-se com o que é belo ou feio, avaliando o valor estético do discurso (PERELMAN; OLBRECHTS-TYTECA, 1996).

O gênero deliberativo (político) destina-se às assembleias, com o objetivo de aconselhar ou desaconselhar acerca de questões, fatos, valores, julgando-os úteis ou nocivos/prejudiciais. Dessa forma, os discursos que deliberam, referem-se ao futuro, instigando a tomada de decisões e efetivando projeções baseadas em fatos.

O gênero judiciário, usado nos tribunais e na vida comum, tem por finalidade acusar ou defender causas, comportamentos, atos, avaliando-os justos ou injustos, pertinentes ou impertinentes. O tempo verbal do referido gênero é o passado. O discurso judiciário concentra-se nos tribunais (juízes e jurados), nos espaços religiosos (sermões utilizados por chefes religiosos) e em outros contextos em que os auditórios citados esclareçam, qualifiquem ou julguem fatos passados.

\subsection{As funções retóricas}

Os estudos retóricos apontam Aristóteles (2005) que traz uma abordagem esclarecedora acerca da natureza da retórica, do valor argumentativo, das funções retóricas e de outros caracteres que tornam um texto mais persuasivo. Conforme esse autor (2005, p. 89), “Todas as pessoas de alguma maneira tentam, em certa medida, questionar e sustentar um 
argumento, defender-se ou acusar". Os questionamentos acerca de determinados argumentos e a sustentação ou defesa de uma tese se materializam por meio de um gênero do qual o retor se apropria.

A perspectiva retórica apresenta categorias específicas que, por sua vez, elucidam o processo persuasivo em textos orais e escritos, estabelecendo a relação de poder, fundada na persuasão e adesão do auditório. Em contrapartida, é comum encontrar textos que não alcançam a adesão do auditório, justamente pela ausência de uma sistemática argumentativa, que possibilite a persuasão por meio da linguagem; logo, não exercem função persuasiva no discurso e não podem ser considerados discursos retóricos, porque o caráter persuasivo da retórica é a capacidade de descobrir o que é adequado a cada caso, com o fim de persuadir (ARISTÓTELES, 2005).

Quanto às categorias de análise de construção retórica, que podem ser encontradas em diversos textos, inclusive no gênero meme, têm-se, a princípio, as funções retóricas que, segundo Reboul (1998), dividem-se em quatro tipos: função persuasiva, função hermenêutica, função heurística e função pedagógica.

A respeito das funções, tem-se a função persuasiva, que se interliga às demais funções de maneira muito íntima, a partir de linguagens verbais e não verbais. Essa função é exemplificada pelo discurso que visa convencer o auditório, a qualquer preço, e que configura o caráter mais poderoso de todas as funções argumentativas, pois se entende que, para ganhar uma causa, independentemente de sua natureza, busca-se a persuasão do auditório, ainda que o orador esteja revestido de intenções diversas. É por essa razão que se pode persuadir para o bem ou para o mal. O tópico abordado nas imagens 6 e 7 configuram um discurso persuasivo, pelos argumentos elencados de modo verbo-visual, baseados em fatos, segundo se explica adiante. 


\section{Imagem 6}

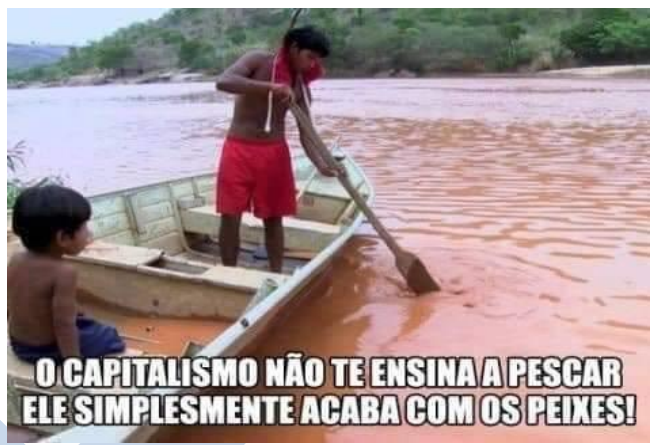

Fonte: RAMALHO, Diogo. Disponível em: https://www.humorpolitico.com.br/category/memes/page/2/. Acesso em 20 fev. 2020.

\section{Imagem 7}

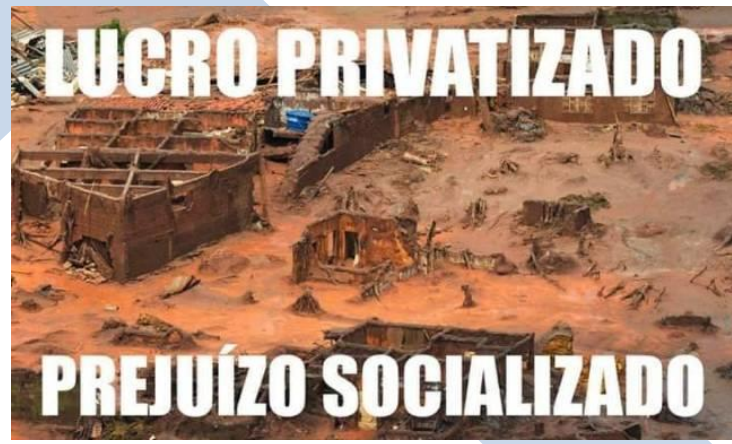

Fonte: RAMALHO, Diogo. Disponível em: https://www.humorpolitico.com.br/category/memes/page/2/. Acesso em 20 fev. 2020.

As imagens 6 e 7 tratam das consequências do rompimento da barragem de minério em Brumadinho, fato que, segundo a Organização das Nações Unidas (ONU), deve ser investigado como crime, devido às consequências catastróficas, envolvendo a morte de muitas pessoas e graves danos ambientais. Ao dizer "O capitalismo não te ensina a pescar. Ele simplesmente acaba com os peixes”, por intermédio da função persuasiva, nessa mensagem, o retor pretende levar o leitor/internauta a crer que os danos causados ao rio e, por extensão, a quem se serve dele (os ribeirinhos), para sobreviver da pesca, não são, pura e 
simplesmente, consequência dos rejeitos de minério da barragem rompida, mas são efeito do capitalismo e do "lucro privatizado" (lucro das empresas), o que se confirma pelos sérios danos evidenciados na imagem 7, ao mostrar que o lucro gerado a poucos acarreta prejuízo a muitos.

Assim, a função retórica empregada nos memes convida o leitor a refletir sobre o efeito cascata envolvendo o capitalismo que representa as indústrias mineradoras, nas imagens; a pesca, forma de sobrevivência daqueles que não usufruíam diretamente da mineração; e a morte dos peixes. Com base nesse raciocínio, é possível afirmar que esse discurso é persuasivo, por se tratar de dois textos que visam mover o leitor a crer que, nem sempre, o capitalismo traz bons resultados.

A função hermenêutica, não menos importante, é a função interpretativa do texto, a qual reforça a necessidade de interpretar um discurso, de maneira coerente, a fim de que seja possível criar estratégias argumentativas. A função hermenêutica aparece associada à persuasiva, provando que as duas se coadunam, pois, na perspectiva da Retórica Moderna, a função hermenêutica é fundamental, para não dizer única, por não se ensinar mais retórica como arte de produzir discurso, mas como arte de interpretá-lo para persuadir, conforme se atesta nas imagens seguintes ( 8 e 9$)$.

\section{Imagem 8}

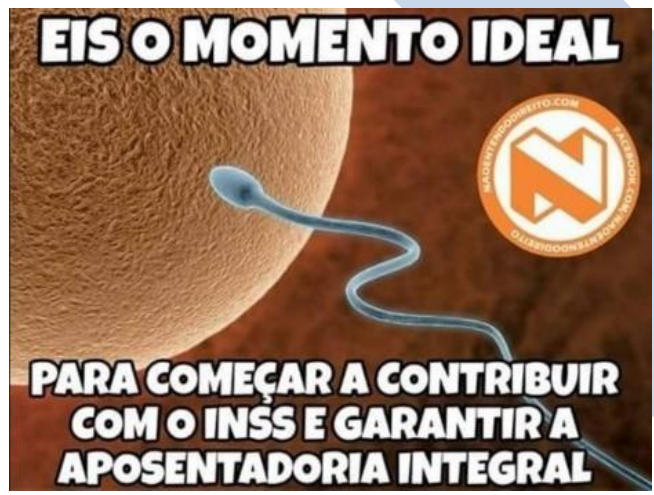

Fonte: Twitter. Disponível em https://emais.estadao.com.br/galerias/comportamento,confira-os-melhores-memes-da-internet-sobre-areforma-da-previdencia,29100. Acesso em: 20 fev. 2020. 


\section{Imagem 9}

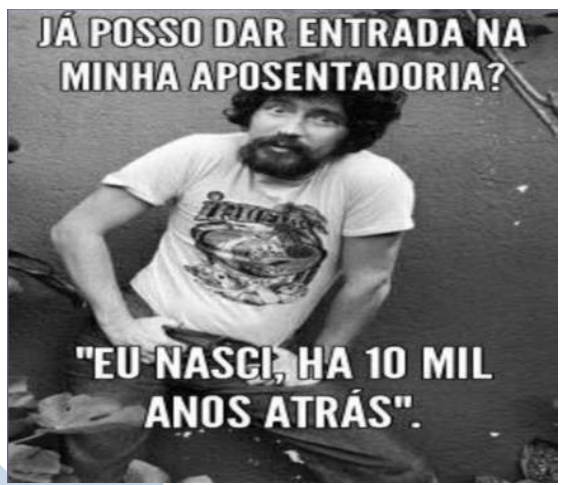

Fonte: Twitter. Disponível em https://emais.estadao.com.br/galerias/comportamento, confira-os-melhores-memes-da-internet-sobre-areforma-da-previdencia,29100. Acesso em: 20 fev. 2020.

A função hermenêutica caracteriza a imagem 8, quando o retor utiliza os elementos que formam tal imagem a fim de reforçar o texto verbal. Isso permite que o auditório (internautas e trabalhadores) interpretem que, no mínimo, terá de trabalhar mais e contribuir com o INSS por mais tempo, para acessar a aposentadoria integral, segundo a Proposta de Emenda à Constituição que altera as regras da Previdência e da Seguridade social. Ironicamente expressa pelo retor como uma reação a tal proposta, a função hermenêutica se constitui, ainda, pelo auditório compreender que o momento ideal para começar a contribuir é o mais breve possível, antes de o espermatozoide - que representa, supostamente, o futuro trabalhador afetado pela reforma - fecundar o óvulo.

A imagem 9 reitera essa interpretação, pois, ao lançar a pergunta “já posso dar entrada na minha aposentadoria?", o próprio retor a responde e faz referência à canção "Eu nasci há dez mil anos atrás”, composta por Paulo Coelho e Raul Seixas e eternizada na voz deste último. Com tal remissão, o retor induz que só nascendo há 10 mil anos e contribuindo desde então para alcançar a aposentadoria integral.

Outra função retórica é a heurística, que objetiva a descoberta das informações mais significativas do discurso. E, por fim, a função pedagógica tem o objetivo de ensinar a compor as ideias e os argumentos. Nesse sentido, faz-se necessário o conhecimento dos 
muitos fatores que se relacionam ao assunto, ao auditório e, sobretudo, ao propósito comunicativo, todos envolvidos na argumentação. A imagem 10 a seguir ilustra bem essas duas funções.

\section{Imagem 10}

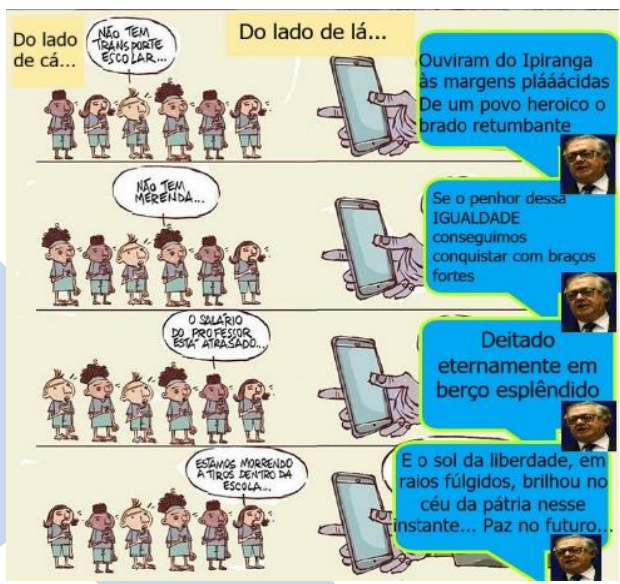

Fonte: Instagram, adaptado pelos autores (2019)

No que se refere à função heurística, presente na imagem 10, o retor, possivelmente, considera como informações mais significativas aquelas que representam os alunos em "Do lado de cá...", ao criticar o envio de uma carta do Ministério da educação (MEC) às escolas pedindo que a carta fosse lida, que alunos, professores e demais funcionários ficassem perfilados, diante da Bandeira do Brasil, se houvesse na instituição de ensino, e que filmasse a leitura de trechos da carta e da execução do hino, incluindo o slogan de cá do atual governo do Brasil.

Nesse sentido, as informações mais importantes no discurso do retor diz respeito ao que precisa ser tomado como prioridades para uma educação brasileira de qualidade, o que abrange a sequência de argumentos "não tem transporte escolar", "não tem merenda", "O salário do professor está atrasado", "Estamos morrendo a tiros dentro da escola”, caracterizada pela função pedagógica. O retor salienta ainda a incoerência que há entre o que o texto expressa "Do lado de cá" e "Do lado de lá", pois as partes do hino, cantadas pela 
figura do atual ministro da educação, no meme, vão de encontro ao que expõe a realidade da educação brasileira, repleta de problemas e fragilidades.

Conforme visto, a retórica define-se principalmente pela arte de persuadir pelo discurso, concretizando nessa definição a sua mais importante função, a chamada função persuasiva. Em seguida, aparece a figura de retórica ironia que se efetiva em posicionamentos críticos e auxilia na persuasão do auditório.

\subsection{A ironia como figura retórica}

A ironia é uma figura de linguagem muito utilizada nos mais variados gêneros discursivos, e seu uso aponta um discurso tendencioso, visto que sua ocorrência remete a um ato de linguagem, o qual necessita da interpretação do sentido pretendido, considerando que esse sentido pode não estar literalmente exposto, exigindo que o auditório/leitor mobiliza uma série de estratégias de ordem sociocognitiva, interacional e textual, sobretudo quando tal figura é utilizada de forma mais comedida.

O objetivo da ironia é criar um efeito de sentido que torna o enunciado, em muitos casos, sarcástico, denotando o propósito daquele que o produz. Quanto a isso, Reboul (1998, p. 132) afirma: "na ironia, zomba-se dizendo o contrário do que se quer dar a entender. Sua matéria é a antífrase, seu objetivo, o sarcasmo, trata-se de uma figura de pensamento, pois tem dois sentidos: [o denotativo ou o conotativo]", o que dependerá do objetivo daquele que enuncia algo, a exemplo das imagens 11 e 12.

\section{Imagem 11}

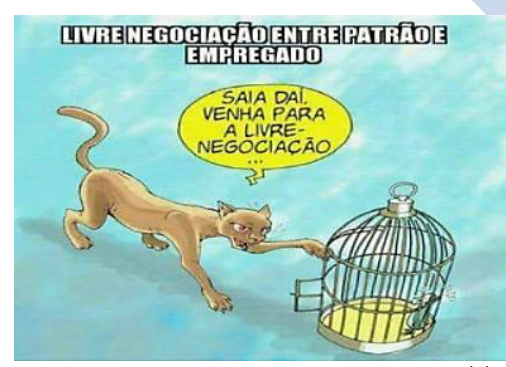

Fonte: Facebook, Twitter e em https://www.huffpostbrasil.com/2017/04/28/esses-memes-explicam-o-porque-da-greve-geral_a_22060523/. Acesso em 27 fev. 2020. 


\section{Imagem 12}

Seu \#patrão te esperando pra 'negociar' seu 'acordo' após a \#ReformaTrabalhista



Fonte: NUNES, Saulo Coelho. Disponível no Twitter e em: https://www.huffpostbrasil.com/2017/04/28/esses-memes-explicam-oporque-da-greve-geral_a_22060523/. Acesso em 20 fev. 2020

Como se observa na imagem 11, o retor utiliza a ironia como um elemento de persuasão, ao problematizar a relação entre patrão x empregado e comparar, a partir dos não verbais, o quão frágil é a posição do empregado diante da livre negociação, resultado da reforma trabalhista, equiparando à vulnerabilidade de um passarinho diante de um gato. Nesse sentido, a linguagem persuasiva na frase "Livre negociação entre patrão e empregado" induz o leitor a perceber, de maneira bem humorada, uma crítica acerca dessa relação de poder comumente vista entre essas duas classes, fundada no efeito contrário ao texto verbal.

Essa posição de fragilidade do empregado numa rescisão contratual de trabalho também é ratificada pela imagem 12 que apresenta o Sr. Richfield, chefe carrasco e cruel de Dino, que costuma culpar o Dino por tudo o que acontece e enganar todos com sua conversa falaciosa, no seriado Família Dinossauros. Já o Dino Silva Sauro trabalha derrubando árvores na companhia de demolição comandada pelo Sr. Richfield, que o intimida frequentemente, por mais que Dino tente apaziguar as situações. No texto verbal da imagem 12, “Seu patrão te esperando pra 'negociar' seu 'acordo’ após a reforma trabalhista”, o retor destaca ainda os termos "negociar" e "acordo", representados pelo contrário, pois 
negociação e acordo fazem parte de uma realidade distante em muitos contextos de trabalho, após a reforma. Ao produzir uma frase irônica, o retor tende a despertar certas emoções no leitor, seja de raiva, indignação, seja de alegria, tristeza, medo.

O conceito de Reboul (1998) contribui significativamente para se compreender o que é a ironia, todavia é preciso repensá-la no sentido de que essa figura de pensamento deixa transparecer em certos textos e espaços sociais aquilo que se pretender dizer, o que significa que tal figura pode ou não deixar bem claros os sentidos e as intenções do retor, pois, dependendo do contexto em que é usada, o retor ironiza, zomba ou satiriza tão explicitamente que não exige do interlocutor grandes esforços para depreender as verdadeiras intenções daquele.

No discurso jornalístico e midiático, a ironia é muito comum, sobretudo em gêneros que se utilizam do humor, tais como: a caricatura, a charge, o cartum, a tirinha, o meme, entre outros. O efeito de sentido da ironia, a partir do sarcasmo, da sátira, somente é percebido se o interlocutor compreender o que se pretende enunciar com essa figura de retórica, já que existem contextos em que não há uma resposta síncrona por parte do interlocutor, pois o efeito irônico fica subentendido, havendo a possibilidade de não ser captado imediatamente.

Esse efeito irônico é de ordem persuasiva, quando tende a mexer com as emoções do auditório pelo caráter dinâmico na comunicação entre orador e auditório, principalmente, por ser necessária a interpretação, quer no sentido literal do discurso, quer no sentido figurado, porque, se o auditório não entender o sentido irônico, denotativa ou conotativamente, o efeito persuasivo será comprometido. Por essa razão, a ironia é uma estratégica que "atrai a atenção das pessoas e confere à comunicação mais vivacidade" (SOUSA, 2001, p. 169), segundo se comprova na imagem 13. 


\section{Imagem 13}

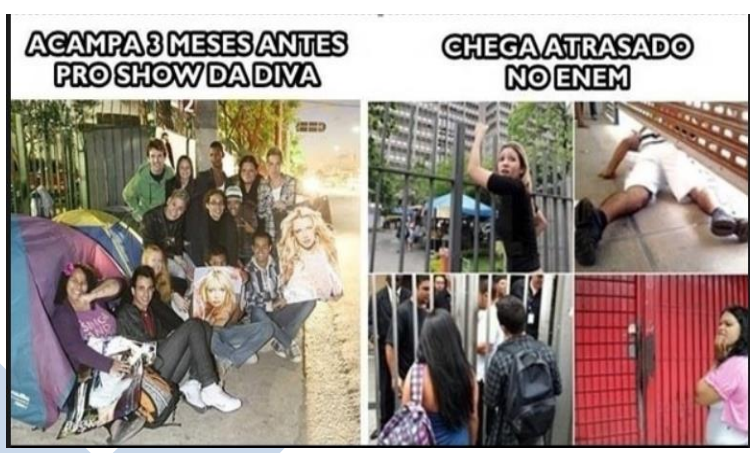

Fonte: Facebook/Professor da Depressão. Disponível em: <https://educacao.uol.com.br ... Acesso em: 20 fev. 2020

A linguagem utilizada pelo retor na imagem 13 é de ordem persuasiva, porque objetiva influenciar os leitores/internautas acerca de determinados comportamentos de pessoas e jovens que se mantêm por muito tempo em filas de espera, para garantir os ingressos ou bons lugares em shows de artistas muito famosos, contrariamente ao que se verifica em dias de aplicação de provas do ENEM, quando muitos candidatos chegam atrasados aos locais de prova e, por isso, não podem realizar as provas.

Ironicamente, o texto verbal "Acampa 3 meses antes pro show da diva. Chega atrasado no ENEM" persuade sarcasticamente, no sentido de ironizar esse comportamento a partir do discurso apresentado, justamente, por estabelecer uma crítica sobre o que é mais ou menos relevante para muitas pessoas, constatando um fato no referido contexto, em se tratando do ato de comparar a importância do momento de entretenimento e o de um ato responsável, um compromisso que reflete a tomada de decisões, quanto ao futuro profissional dos referidos jovens.

Em textos que circulam na mídia, o objetivo nem sempre será apenas traduzir de modo referencial um fato que realmente aconteceu, mas ambiguizar ou contradizer, semanticamente, em dois níveis (literal e metafórico), o discurso, abrindo possibilidades para novas leituras do que se enuncia sobre algo ou alguém. O fato é que, quando o retor faz uso da ironia, ele molda ou mascara o discurso, a partir do desvio da normalidade, da língua- 
padrão, ridicularizando ou dessacralizando o referente, seus valores culturais, sociais, morais ou até acontecimentos de uma determinada sociedade, exigindo do auditório a recuperação do sentido, por intermédio de aspectos textuais e contextuais, numa relação entre texto-situação e situação-texto, elementos contextuais e contextuais, com vistas a decifrar o mascaramento do discurso.

Seja pela expressão literal e objetiva dos sentidos, seja pela subjetividade e metaforização do discurso, a ironia representa o contrário e sua leitura se realiza apenas na relação retor-discurso-auditório, visto que esse auditório tem de estar a postos para compreender o contrário numa interlocução. O retor, ironista, por sua vez, encontra maneiras de captar a atenção do auditório social e contar sua adesão. Em não havendo esse diálogo, a ironia não se concretiza, pois o conteúdo pode conter sinalizações sutis - como pode não contêlas, satirizando, de modo explícito, o referente -, de tal modo que a participação do outro para a compreensão dos valores expressos pelo retor é fundamental, e isso exige que os internautas captem esse discurso mascarado, detectando o foco da mensagem.

A ironia é uma figura de retórica pelo potencial persuasivo desempenhado em seu funcionamento, no entanto seu aspecto interpretativo reside numa base de inferência onde o aspecto contextual evoca uma dupla funcionalidade. A ironia pragmática sugere uma aplicação intencional onde o orador deseja ser irônico, sarcástico em seu discurso; a ironia cognitiva registra uma competência esquemática pelo modo sistemático, envolvendo uma situação real e uma projetada, que significa o contrário do real, sendo amena ou cruel, sutil ou grosseira, amarga ou engraçada, estabelece uma abordagem análoga entre duas faces, uma real e uma fictícia, e ressalta um argumento de incompatibilidade pelo ridículo, manifesto em textos orais ou escritos, permitindo uma avaliação por parte do auditório, que pode ou não interpretar bem a referida figura.

Em se tratando da ironia, evidente no gênero textual meme, Passetti (1995, p. 54) enuncia: "na ironia verbal, com que operamos, há também um observador de fatos ou atitudes contraditórias, mas este observador, num processo interativo e intersubjetivo, pretende mostrá-los ou deles destacar aspectos, com vistas a persuadir o seu interlocutor". 
Assim, por estar no campo das ideias, a ironia resulta da atitude do orador em função daquilo que o auditório irá interpretar, num propósito interativo e subjetivo.

No gênero meme da internet, empregou-se a ironia para provocar um efeito de persuasão a partir do sarcasmo, característica que se fundamenta em uma ação da linguagem, quando satiriza a imagem de alguém ou determinada situação. É nessa conjuntura de negociação que se manifestam as duas faces da adesão do auditório, seja por meio da persuasão, seja a partir do convencimento.

\section{Considerações finais}

Os memes são textos que utilizam informações, ideias, acontecimentos, agregando elementos verbais, não verbais ou audiovisuais para divulgar um produto, produzir humor, satirizar ou estabelecer uma crítica a algo ou alguém, por intermédio de interfaces com outros gêneros textuais ou ferramentas digitais, programas de edição de fotos, produzindo manifestações imagéticas, audiovisuais e verbo-visuais específicas na internet.

O diálogo entre a teoria retórica e as imagens mostrou que os memes são constituídos de estratégias argumentativas - tríade aristotélica, funções retórica e ironia como figura retórica -, e a dinâmica interacional entre o ethos (produtor do meme), logos (linguagem e mensagem propriamente dita) e o pathos (as emoções do público-leitor/internautas) permite caracterizar esse gênero textual no que concerne ao domínio social da comunicação, aos aspectos tipológicos textuais e à capacidade de linguagem dominante, sem reduzi-lo a nomenclaturas engessadas e estanques, tendo em vista os propósitos comunicativos dos interlocutores, os contextos histórico-sociais de onde provêm, além de outros aspectos caracterizadores do gênero apontado, como a mutação, seleção natural, hereditariedade, longevidade, fecundidade, fidelidade das cópias e expansividade.

Além disso, quanto à circulação da informação, o meio digital possibilitou uma dinâmica diferenciada, porque a mensagem veiculada na internet amplia as possibilidades de leitura e de interação entre escritor, texto e leitor, permitindo também a geração de novos sentidos, mobilizados por aspectos cognitivos do leitor, por seus conhecimentos prévios e 
pelos elementos contextuais (aspectos sociais, políticos, ideológicos, culturais, entre outros) e cotextuais (aspectos linguísticos) apresentados pelos memes.

No que se refere à perspectiva argumentativa, a ironia pode ser entendida como um recurso de persuasão, o qual gera um estado de atenção no texto, reflete o ethos, isto é, o caráter daquele que se vale dessa face; o pathos, conjunto de valores e paixões/emoções do auditório; e o logos, o próprio discurso. Nessa interligação entre os três elementos, o ethos do orador transmitiu uma imagem avaliativa acerca das várias temáticas evidenciadas nos memes, despertando sentimentos (pathos) no auditório, os quais podem ser de aprovação ou de reprovação perante as ideias apresentadas no discurso persuasivo (logos).

\title{
RHETORICAL ASPECTS IN THE TEXTUAL GENRE “MEME” ON THE INTERNET
}

\begin{abstract}
This study aims to analyze rhetorical specificities in the textual genre meme, notably rhetorical functions and irony as a rhetorical figure, in internet memes. The methodology adopted for the study of memes is of a qualitative nature, describing and interpreting the linguistic idiosyncrasies that make this genre happen, with regard to rhetorical functions and the ironic rhetorical figure, as well as making qualitative analysis a continuous process of construction versions of reality (FLICK, 2009). The sampling for the analysis consists of memes available on the web. Theoretical assumptions are based on Modern Rhetoric, from Meyer (2007), Perelman and Olbrechts-Tyteca (1996), Reboul (1998), Sousa (2001), among others, as well as being based on the studies of Barreto (2015), Horta (2015) and Calixto (2017), which bring discussions about the textual genre meme. The results show that memes have rhetorical mechanisms, in order to discuss controversial social problems, through the support of opinions or the refutation of positions taken by retectors as subjects of social language practices. The relevance of the theme is given by bringing an argumentative approach to the genre meme on the internet, based on the perspective of Modern Rhetoric.
\end{abstract}

KEYWORDS: Rhetorical functions; Internet; Irony; Meme; Modern Rhetoric.

\section{REFERÊNCIAS}

ABREU, Antônio Suárez. A arte de argumentar: gerenciando razão e emoção. 7, ed. Cotia: Ateliê, 2004.

ARISTÓTELES. Arte retórica. 2. ed. Revisão: Levi Condinho. Aristóteles. Lisboa: Imprensa Nacional-Casa da Moeda, 2005.

BARRETO, Krícia Helena. Os memes e as interacões sociais na internet: uma interface entre práticas rituais e estudos de face. 2015. 147 f. Tese (Doutorado em Linguística) - Faculdade de Letras, Universidade Federal de Juiz de Fora, Juiz de Fora, 2015. 
CALIXTO, Douglas de Oliveira. Memes na internet: entrelaçamentos entre Educomunicação, cibercultura e a "zoeira de estudantes nas redes sociais. 2017. 233 f. Dissertação (Mestrado em Ciências da Comunicação) - Escola de Comunicações e Artes, Universidade de São Paulo, São Paulo, 2017.

CITELLI, Adilson. Linguagem e persuasão. 16. ed. rev. atual. São Paulo: Ática, 2005.

DOLZ, Joaquim; SCHNEUWLY, Bernard. Gêneros e progressão em expressão oral e escrita - elementos para reflexões sobre uma experiência suíça (francófona). In:

SCHNEUWLY, Bernard; DOLZ, Joaquim e colaboradores. Gêneros orais e escritos na escola. Tradução e organização Roxane Rojo e Glaís Sales Cordeiro. Campinas, SP: Mercado de Letras, 2004.

FLICK, Uwe. Introdução à pesquisa qualitativa. Tradução Joice Elias Costa. 3. ed. Porto Alegre: Artmed; Bookman, 2009.

GOMES, Luiz Fernando. Redes sociais e escola: o que temos de aprender? In: ARAÚJO, Júlio; LEFFA, Vilson. Redes sociais e ensino de linguas: o que temos de aprender? 1. ed. São Paulo: Parábola, 2016.

HALLIDAY, Teresa Lúcia. O que é retórica. São Paulo: Brasiliense, 1999.

HORTA, Natália Botelho. O meme como linguagem da internet: uma perspectiva semiótica. 2015. 190 f. Dissertação (Mestrado em Comunicação) - Faculdade de Comunicação, Universidade de Brasília, Brasília, 2015.

MEYER, Michel. A retórica. Revisão técnica Lineide Salvador Mosca; tradução Marly N. Peres São Paulo: Ática, 2007.

PASSETTTI, Maria Célia Cortez. O discurso irônico: análise da argumentação irônica em textos opinativos da Folha de S. Paulo. 1995. 196 f. Dissertação (Mestrado em Filologia e Linguística Portuguesa) - Faculdade de Ciências e Letras, Universidade Estadual Paulista Júlio de Mesquita Filho, Assis, São Paulo, 1995.

PERELMAN, Chaïm; OLBRECHTS-TYTECA, Lucie. Tratado da Argumentação: a nova retórica; tradução Maria Ermantina Galvão G. Pereira. Revisão de tradução Eduardo Brandão 2. ed. São Paulo: Martins Fontes, 1996.

REBOUL, Olivier. Introdução à retórica. Tradução Ivone Castilho Benedetti. São Paulo: Martins Fontes, 1998.

SOUSA, Américo. A persuasão. Covilhã: Serviços Gráficos da Universidade da Beira Interior, 2001.

Recebido em: 01/05/2020.

Aprovado em: 25/05/2020. 